\title{
Cultural adaptation of the Pieper-Zulkowski Pressure Ulcer Knowledge Test for use in Brazil
}

\author{
Adaptação cultural do instrumento Pieper-Zulkowski Pressure Ulcer Knowledge Test para o Brasil \\ Adaptación cultural del instrumento Pieper-Zulkowski Pressure Ulcer Knowledge Test para Brasil
}

\section{Soraia Assad Nasbine Rabeh', Simon Palfreyman", Camilla Borges Lopes Souza', Rodrigo Magri Bernardes', Maria Helena Larcher Caliri'}

' Universidade de São Paulo, Ribeirão Preto College of Nursing. Ribeirão Preto, São Paulo, Brazil.

"University of Alberta, Faculty of Nursing. Edmonton, Alberta, Canada.

How to cite this article:

Rabeh SAN, Palfreyman S, Souza CBL, Bernardes RM, Caliri MHL. Cultural adaptation of the

Pieper-Zulkowski Pressure Ulcer Knowledge Test for use in Brazil. Rev. Bras. Enferm. [Internet]. 2018;71(4):1977-84.

DOI: http://dx.doi.org/10.1590/0034-7167-2017-0029

Submission: 02-07-2017 Approval: 09-22-2017

\begin{abstract}
Objective: To carry out the cultural adaptation of the Pieper-Zulkowski Pressure Ulcer Knowledge Test (PZ-PUKT) for use in Brazil and analyze the internal consistency of the adapted version. Method: This was a methodological study. The PZPUKT is a knowledge test consisting of 72 items, divided into: prevention, staging, and wound description. The present study was developed in two phases: (1) translation of the questionnaire from English to Brazilian Portuguese, back-translation, and assessment of equivalence between the original and back-translated version by an expert panel; (2) pre-testing with nurses. Results: The questionnaire showed face and content validity according to the opinions of the experts. Cronbach's alpha for the total test score was higher than 0.70 . The adapted version presented satisfactory internal consistency for the studied sample. Conclusion: The adapted version of the instrument for Portuguese can be used in intervention studies as a tool to measure "nursing knowledge about pressure injury/ulcers" as a dependent variable.
\end{abstract}

Descriptors: Validation Studies; Evidence-Based Nursing; Ulcer Wounds; Knowledge, Health Attitudes and Practices; Wounds and Injuries.

\section{RESUMO}

Objetivo: Realizar adaptação cultural do instrumento Pressure Ulcer Knowledge Test (PZ-PUKT), para uso no Brasil e analisar a consistência interna da versão adaptada. Método: Estudo metodológico. O PZ-PUKT é um teste de conhecimento com 72 itens, distribuídos em: prevenção, estadiamento e descrição da ferida. O projeto foi desenvolvido em duas fases: (1) tradução do instrumento do inglês para o português do Brasil, retrotradução e avaliação de equivalência das versões por um comitê de especialistas; (2) préteste com enfermeiros. Resultados: $\mathrm{O}$ instrumento demonstrou validade de face e conteúdo na opinião de especialistas. O valor do coeficiente alfa de Cronbach, para o escore total, foi acima de 0,70. A versão adaptada apresentou consistência interna satisfatória para a amostra estudada. Conclusão: $\mathrm{O}$ instrumento validado para o português tem possibilidade de ser utilizado em estudos de intervenções como instrumento para mensurar a variável dependente: Conhecimento do enfermeiro sobre lesão/úlcera por pressão. Descritores: Estudos de Validação; Enfermagem Baseada em Evidências; Úlcera por Pressão; Conhecimentos, Atitudes e Prática em Saúde; Ferimentos e Lesões.

\section{RESUMEN}

Objetivo: Realizar adaptación cultural del instrumento Pressure Ulcer Knowledge Test (PZ-PUKT) para uso en Brasil y analizar la consistencia interna de la versión adaptada. Método: Estudio metodológico. El PZ-PUKT es un test de conocimiento con 72 ítems divididos en: prevención, estadificación y descripción de la herida. El proyecto se desarrolló en dos fases: (1) traducción del instrumento del Inglés al Portugués brasileño, retrotraducción y evaluación de equivalencia de versiones por un Comité de especialistas; (2) prueba piloto con enfermeros. Resultados: El instrumento demostró validez de apariencia y contenido, según los especialistas. El valor del 
coeficiente Alfa de Cronbach para el puntaje total fue superior a 0,70. La versión adaptada demostró satisfactoria consistencia interna para la muestra estudiada. Conclusión: El instrumento validado para el Portugués podrá ser utilizado en estudios de intervenciones, como instrumento para mensurar la variable dependiente "Conocimientos del enfermero sobre lesión/úlcera por presión".

Descriptores: Estudios de Validación; Enfermería Basada en la Evidencia; Úlcera por Presión; Conocimiento; Conocimientos, Actitudes y Práctica en Salud; Heridas y Lesiones.

\section{CORRESPONDING AUTHOR Karin Viégas E-mail: kviegas@gmail.com}

\section{INTRODUCTION}

In recent years, there have been changes in the demographic and epidemiological profile of the population. This has been accompanied by an increase in longevity, the number of individuals living with chronic-degenerative conditions and mortality rates due to external causes. Together, these factors contribute to a population predisposition for occasional complications, such as pressure injury $(\mathrm{PI})^{(1-3)}$.

Pressure injury is defined as harm caused to the skin and/ or underlying soft tissues. These usually occur over bony prominences or are related to the use of medical devices or other $\operatorname{artifacts}^{(3)}$.

Considered an adverse event and a negative indicator of quality of healthcare, $\mathrm{PI}$ incurs high financial and emotional costs for patients, family members and health services. Their occurrence is directly related to patient care and safety ${ }^{(3-7)}$.

At the international level, several directives have been published regarding clinical practice, guiding PI prevention and treatment, interdisciplinary approaches, and educational programs, with the goal of implementing evidence-based PI care $^{(1-3)}$.

International directives highlight the dynamic and systematic nature of chronic wound prevention and treatment, which includes clinically evaluating patients and wounds, controlling or eliminating etiological factors and co-morbidities, and preparing wound beds. These activities require that nurses be constantly aware of the latest scientific and technological knowledge, thus ensuring quality care practices ${ }^{(8)}$.

In both the Brazilian and international literature, several studies have assessed the knowledge of nursing professionals and students about pressure injury/ulcer prevention and treatment. However, these studies show that members of healthcare teams present limitations in using the recommended PU prevention and treatment directives. Thus, it is essential that strategies be employed to favor their dissemination and implementation in clinical practice ${ }^{(9)}$.

In the United States, Pieper and Mott ${ }^{(10)}$ developed the Pressure Ulcer Knowledge Test (PUKT). In its original version, the first part contained 20 items related to sociodemographic and educational data and information search strategies. The second part, which refers to the actual test, consisted of 47 items divided into three subscales: 33 risk factor/prevention items; 7 staging items; and 7 wound description items. The answer options were: "true," "false," and "don't know". Validity and reliability were reported in the study by Pieper and Mattern ${ }^{(11)}$, with Cronbach's alpha at 0.85 .

The authors ${ }^{(10)}$ assessed the knowledge of 228 American nurses about PU prevention, staging, and description using the self-administered test (PUKT). This test was based on the recommendations set forth by the Agency for Health Care Policy and Research (AHCPR). The results of the study indicated a knowledge deficit: only $10 \%$ of the nurses had ever read the AHCPR guidelines. Professionals who had attended a lecture and/or read some article on the theme demonstrated significantly higher knowledge than those who had not.

Another study conducted by Pieper and Mattern ${ }^{(11)}$ with 75 intensive care nurses using the same test revealed knowledge deficits. Only $12 \%$ of the professionals were knowledgeable about the guidelines. In that study, the test results were not affected by years of nursing experience, type of nursing education, or reading articles about PU. The only nurses who demonstrated significant knowledge were those who had watched some lecture on the topic.

In Canada, Sinclair et al. ${ }^{(12)}$ implemented and assessed several educational standardized workshops administered with nursing technicians and nurses, comparing their knowledge preintervention, and at two post-intervention times, using the test developed by Pieper and Mott ${ }^{(10)}$. The results showed that nurses obtained higher knowledge scores at the two post-test times, although with a reduction between the first and second times.

In Brazil, Caliri, Miyazaki, and Pieper ${ }^{(13)}$ assessed the knowledge of nursing graduates about PU prevention, staging, and description based on the AHCPR framework. The results also showed knowledge deficits, with significantly higher scores among those who participated in extracurricular internships and/or searched the internet for information on the matter.

Rangel $^{(14)}$ investigated the knowledge of nurses in a private health service about PU prevention and identified that knowledge scores were relatively higher among professionals who had participated in ongoing education programs provided by the institution about the topic. Additionally, 50\% of the nurses mentioned prevention practices and treatment conducts considered inadequate, considering that most of the dressings were carried out by nursing aides.

The test developed by Pieper and Mott ${ }^{(10)}$ was adapted to Portuguese by Fernandes, Caliri, and Haas ${ }^{(15)}$, resulting in 41 items, with six classification and staging items, two wound description items, and 33 prevention items. Miyazaki, Caliri, and Santos ${ }^{(16)}$ used the test to assess knowledge about PU prevention among a sample of 386 nursing professionals at a university hospital, of which $35.2 \%$ were nurses and $64.8 \%$ were nursing aides/technicians, who worked with direct bedside care of adult and older adult patients. The mean percentage of correct scores on the knowledge tests among nurses was $79.4 \%$ and among nursing aides/technicians, $73.6 \%$. However, some PU assessment/classification and prevention items presented percentages of correct scores lower than $60 \%$ and $50 \%$, respectively. Among nursing aides and technicians, the percentage of correct scores was negatively correlated with time since graduation and time at the service. 
Studies with nursing students and professors have also shown that the knowledge acquired was not sufficient to prepare future nurses to care for individuals with chronic wounds. This was especially true in terms of wound assessment and the prescription of nursing interventions ${ }^{(17-20)}$.

Nurses and nursing staff should work to promote, maintain and recover skin integrity. Individuals should receive comprehensive care, focused on the Systematization of Nursing Care. According to article 8 of the Law of professional practice, nurses have the exclusive ability to prescribe nursing care, which includes planning and prescribing care to PU patients ${ }^{(21-22)}$.

Chronic wound prevention and management measures should be part of the list of basic nursing skills. Based on scientific knowledge and the assessment of a patient's clinical conditions, such skills have the potential to promote together with the health and nursing staff, the best care possible ${ }^{(22)}$.

In recent decades, the production of knowledge and technologies to care for individuals with chronic wounds has advanced significantly, presenting the need for professionals to keep updated on scientifically-based information ${ }^{(23)}$.

Pieper and Zulkowski ${ }^{(24)}$ have also developed an updated version of the PUKT ${ }^{(10)}$, the Pieper-Zulkowski Pressure Ulcer Knowledge Test (PZ-PUKT). New items have been added based on the most recent pressure injury/ulcer prevention and treatment recommendations ${ }^{(25)}$.

In light of the above and considering the need to provide access to an updated questionnaire to assess the knowledge of nurses and nursing students about pressure injury/ulcers, it is relevant to conduct a cultural adaptation and validation of the PZ-PUKT instrument for use in Brazilian Portuguese. This questionnaire can be used in intervention studies to measure nursing knowledge about pressure injury/ulcers as the dependent variable.

\section{OBJECTIVE}

To carry out the translation and cultural adaptation of the Pieper-Zulkowski Pressure Ulcer Knowledge Test (PZ-PUKT) for use in Brazilian Portuguese and to analyze the internal consistency of the adapted version of the questionnaire.

\section{METHOD}

\section{Ethical aspects}

The present study was approved by the Research Ethics Committee of the Ribeirão Preto College of Nursing, at University of São Paulo. All the participants were given verbal and written information about the nature of the study and those who agreed to participate signed an informed consent form. Permission to conduct the cultural adaptation process and psychometric studies of the PZ-PUKT was obtained from the authors, Barbara Pieper of the College of Nursing at Wayne State University de Detroit, Michigan, and Karen Zulkowski of the College of Nursing at Montana State University, Bozeman, Montana, in the United States.

\section{Theoretical-methodological framework}

Beaton $^{(26)}$ states that most questionnaires have been developed in English-speaking countries and in order to be used in countries with other languages and cultures, they must undergo a cultural adaptation process. Not only must the items be translated, but also adapted culturally to maintain the same content validity as in the source instrument ${ }^{(26)}$.

According to the theoretical-methodological framework used, the cultural adaptation process took place as described below ${ }^{(26)}$.

\section{Type of study}

This was a methodological study with the aim of translating and culturally adapting the Pieper-Zulkowski Pressure Ulcer Knowledge Test (PZ-PUKT) for use in Brazilian Portuguese.

\section{Methodological procedures}

The PZ-PUKT consists of 2 parts. Part 1 contains 11 items regarding sociodemographic data, and part 2, 72 items that refer to knowledge, divided by the authors into three sub-scales: prevention (20 items), staging (25 items) and wound description (27). The PZ-PUKT is scored based on the answers to the questionnaire items. Answer options are "true," "false," and "don't know," with 42 true items and 30 false items.

To assess construct validity, internal consistency and stability (test-retest), two samples of nurses were used: 108 in the first stage and 95 in the second stage. Cronbach's alpha was 0.80 for the 72 items, indicating that, considering the total test score, the PZ-PUKT was valid and reliable. The sample size was considered a limitation, as it was insufficient to validate sub-scores and thus, the authors recommended further studies with larger samples ${ }^{(24)}$.

\section{Translation and cultural adaptation procedures}

The present study was developed in two phases. Phase 1 consisted of the cultural adaptation process, and Phase 2, analysis of internal consistency of the items ${ }^{(26-27)}$.

- Phase 1: Culturally adapting a psychometric instrument involves steps that allow for semantic, idiomatic, experiential and conceptual components to be adjusted, obtaining greater equivalence with its original version. The adaptation process consisted of the following steps:

- Translating the questionnaire into Brazilian Portuguese: The English version of the PZ-PUKT was translated into Brazilian Portuguese by two independent translators, both with mastery of the English and Portuguese language and aware of the objectives and concepts of the study, resulting in two Portuguese versions. To obtain the first synthesis, a meeting was conducted with the researchers (main researcher and research group leader) and the translators. The two translated versions were assessed with the goal of comparing them and listing whether the items maintained semantic equivalence with the original questionnaire. This step resulted in the first synthesis version in Portuguese.

- Assessment by a panel of experts: The translation was analyzed in terms of its conceptual, semantic and idiomatic equivalence by a panel of five nurses with knowledge about the theme, the adopted methodology, and with proficient Portuguese and English skills. 
All the nurses had graduate degrees and clinical and research experience on the theme. After contacting the participants, the original version and the first synthesis version in Portuguese were sent via email, together with an informed consent form. A space was provided on the questionnaire on which participants could record and justify any disagreements and/or suggestions regarding terms in the translated version. A two-week deadline was set for the documents to be returned. In the next step, a meeting was conducted with the researchers, in which the suggestions and justifications sent back were analyzed. Changes were approved when agreement among the panel was $80 \%$. This step resulted in the second synthesis version in Portuguese.

- Back translation of the Portuguese version into English. This was conducted by two independent translators: the first was born in an English-speaking country and the other went to university in the United States, both fluent in English and Portuguese, with experience in translating documents in the health area. The objective of this step was to verify whether the translation of the questionnaire reflected the content contained in the source version. This step resulted in two back-translated versions in English. Next, the researchers and the translators met to compare the translated, back-translated, and source versions and thus assess possible semantic differences and reach a consensus about the terms most equivalent to the source version. The back translation was sent to the authors of the instrument, professors Barbara Pieper and Karen Zulkowski, in the United States, for their appraisal, resulting in the corrected and approved English version.

- Semantic analysis of the items: a third synthesis version in Portuguese was submitted to semantic analysis to a sample of five nurses who worked at a university hospital with pressure injury/ulcers, selected by convenience, and who voluntarily agreed to participate in this step, signing an informed consent form. The participants assessed the questionnaire in terms of its wording, presentation, and comprehensibility of the terms used in the items. The goal of this step was to reach a better understanding of the target audience, which resulted in the fourth synthesis version in Portuguese to be used in pre-testing.

- Phase 2 - Pre-Testing. The questionnaire was administered to a sample of its target population to verify overall acceptance and understanding of the items ${ }^{(26)}$.

\section{Study location}

The study was conducted in the clinical, surgical, intensive care, coronary, neurological and emergency units of a university hospital located in the state of São Paulo, Brazil.

\section{Source of data}

The convenience sample consisted of 54 nurses who accepted to participate and who were working at the time of data collection.

\section{Data collection and organization}

The data were gathered between July and August 2016, both during day and night shifts.

The participants received a copy of the PZ-PUKT in Portuguese, as well as the instructions for completing it. The questionnaire is self-administered and was applied during work hours. The data were collected by contacting individuals at the hospital, at a time suggested by the coordinating nurse that would not interfere with work activities. The questionnaire took an average of 20 minutes to be completed. After completion, participants were asked about the possible difficulties and understanding of the adapted version of the PZ-PUKT. The number of participants in this step was in line with that recommended by the literature (minimum of 30 to 40 subjects) ${ }^{(26)}$.

\section{Data analysis}

The data were processed and analyzed using the Statistical Package for the Social Sciences software program, version 21.

\section{Descriptive analysis}

The demographic/educational variables were submitted to descriptive analysis to identify professional profiles. Participants received a total test score (percentage of correct answers out of the 72 questionnaire items) and sub-scores for each domain (percentages of correct scores in the prevention, staging and wound description subscales). The answer "don't know" was considered incorrect. All the participants answered all the questions. Correlation between total scores and social and educational variables was measured using Pearson's coefficient of linear correlation.

\section{Inferential analysis}

The Mann-Whitney test was employed to compare the total score and the sub-scores with the dichotomous socio-educational variables. The Kruskal-Wallis test was used to compare total score and sub-scores obtained for the non-dichotomous variables "time of practice" and "highest degree obtained".

\section{Psychometric analysis}

Cronbach's alpha was calculated to test the internal consistency of the adapted questionnaire. These values range from zero to one. The higher the value, the higher the measure's internal consistency, and values over 0.70 are considered acceptable for reliability ${ }^{(28-29)}$.

\section{RESULTS}

After the PZ-PUKT test was translated into Portuguese, the expert panel analyzed the test for conceptual, semantic, and idiomatic equivalence. After receiving suggestions, some terms were changed, excluded or replaced.

Changes were made to items regarding sociodemographic and educational data. Regarding the answer options of item 1 "Onde você trabalha?" (Where do you work?), the term "Cuidado de longa permanência" (Long-term care) was replaced with "Instituição de longa permanência" (Long-term institution); "Cuidado domiciliar" (Home care) with "Assistência domiciliar" (Home healthcare) and "Prática privada" (Private practice) with "Prática autônoma" (Autonomous practice). In 
item 4, "Categoria profissional" (Professional category), the answer option "Mestre/Doutor" (Master's/PhD) was changed to "Mestre em enfermagem/Doutor em enfermagem" (Master's in Nursing/PhD in nursing).

In item 7, "Certificação em qualquer especialidade clínica" (Certification in any clinical specialty) was changed to "Especialização em alguma área clínica" (Specialization in any clinical area), and "Certificado como especialista em ferida" (Certified injury expert) was dismembered into "Especialização em Estomaterapia" (Specialization in stomatherapy) and "Enfermagem em dermatologia" (Dermatology nursing). Item 10, "Você já buscou informação sobre úlcera por pressão na Web?" (Have you ever searched for information on pressure ulcers on the Web?) was changed to "Você já buscou informação sobre lesão/úlcera por pressão na internet?" (Have you ever searched for information about pressure injury/ulcers on the internet?).

Of the 72 test items, 12 underwent terminology changes. Wording was modified and new terms/words were included, such as "pressure injury/ulcer" in agreement with the international guidelines set forth by the National Pressure Ulcer Advisory Panel (NPUAP) $)^{(3)}$. Furthermore, the language was adjusted for cultural adaptation.

This synthesis Portuguese version in Portuguese was backtranslated and sent to the authors of the source version, who replaced/reformulated 7 items, as shown in Table 1. As these changes were not foreseen in the methodology, the researchers met once more to correct the Portuguese and English versions. Next, the test was presented once again to the expert panel, which agreed with the changes made.

The authors also recommended reallocating items in the sub-scales as per the international practice guidelines for the prevention and treatment of pressure injury developed by the NPUAP/European Pressure Ulcer Advisory Panel (EPUAP)/Pan Pacific Pressure Ulcer Alliance (PPPIA) ${ }^{(2)}$. The Portuguese version of PZ-PUKT was adapted based on a review of the questions and conceptual analysis carried out by a panel of researchers. The number of items increased from 20 to 29 in the prevention sub-scale, and fell from 25 to 20 in the staging sub-scale and 27 to 23 in the wound description sub-scale.

In the semantic analysis phase, the group of nurses expressed no difficulties in understanding the items and offered no suggestions.

Of the 54 participants in the pre-testing phase, 46 (85.2\%) were women, with a mean age of 36.4 years $(\mathrm{SD}=8.6$; ranging between 24 and 65 years), 31 (57.4\%) had ten or more years of practice. Regarding highest degree obtained, 34 (63.0\%) had a baccalaureate nursing degree, $7(13.0 \%)$ had a graduate degree, and $13(24.0 \%)$ had specialization degrees, of which only $2(3.7 \%)$ had specialized in stomatherapy, zero in dermatology, and 11 (20.4\%) in some other clinical area. Regarding continuing professional development, 50 (92.6\%) had searched for information on the internet; however, only 12 (22.2\%) had read the NPUAP/EPUAP clinical practice guideline, and in the year prior to the study, $33(61.1 \%)$ had attended lectures and $24(44.4 \%)$ had read an article or book chapter on the topic.

Table 1 compares the total test scores with the sub-scores by sociodemographic and educational variables.

There were statistically significant differences in the total test scores and sub-scores between participants who had attended lectures about pressure injury/ulcers in the year prior to the study, and participants who had attended lectures more than a year prior to the study.

Chart 1 - Comparison of the original English version corrected by the authors and the synthesis version in Portuguese with the modified items, Ribeirão Preto, São Paulo, Brazil, 2016

\begin{tabular}{|c|c|c|}
\hline Item & PZ-PUKT Corrected English Version & Final Portuguese Version with modified items \\
\hline 46 & $\begin{array}{l}\text { Patients who are spinal cord injured need knowledge about } \\
\text { pressure injury/ulcer prevention and self-care. }\end{array}$ & $\begin{array}{l}\text { Pacientes com lesão de medula espinhal precisam ter } \\
\text { conhecimento sobre a prevenção da lesão/úlcera por pressão } \\
\text { e o autocuidado. }\end{array}$ \\
\hline 48 & $\begin{array}{l}\text { A mucosal membrane pressure injury/ulcer is found on } \\
\text { mucous membrane as the result of medical equipment used at } \\
\text { that time on that location; this pressure injury is not staged. }\end{array}$ & $\begin{array}{l}\text { Uma lesão/úlcera por pressão pode ser encontrada em uma } \\
\text { membrana mucosa, como resultado do uso de equipamento } \\
\text { médico no local, e essa lesão não pode ser estadiada. }\end{array}$ \\
\hline 56 & $\begin{array}{l}\text { To help prevent pressure injury/ulcers, the head of the bed } \\
\text { should be elevated at a } 45 \text {-degree angle or higher. }\end{array}$ & $\begin{array}{l}\text { Para auxiliar na prevenção da lesão/úlcera por pressão, a } \\
\text { cabeceira da cama deve ser elevada em ângulo de } 45 \text { graus } \\
\text { ou mais. }\end{array}$ \\
\hline 58 & $\begin{array}{l}\text { Pressure injury/ulcers may be avoided in patients who are } \\
\text { obese with use of properly sized equipment. }\end{array}$ & $\begin{array}{l}\text { As lesões/úlceras por pressão podem ser evitadas em } \\
\text { pacientes que são obesos com o uso de equipamento de } \\
\text { tamanho apropriado. }\end{array}$ \\
\hline 67 & $\begin{array}{l}\text { Alginate dressings can be used for heavily draining pressure } \\
\text { injury/ulcers or those with clinical evidence of infection. }\end{array}$ & $\begin{array}{l}\text { Cobertura de alginato pode ser utilizada para lesão/úlcera } \\
\text { por pressão com muito exsudato ou com evidência clínica de } \\
\text { infecção. }\end{array}$ \\
\hline 68 & $\begin{array}{l}\text { Deep tissue injury will not progress to another injury/ulcer } \\
\text { stage. }\end{array}$ & $\begin{array}{l}\text { Lesão tissular profunda não progride para lesão/úlcera de } \\
\text { outra categoria/estágio. }\end{array}$ \\
\hline 72 & Bacteria can develop permanent immunity to silver dressings. & $\begin{array}{l}\text { As bactérias podem desenvolver imunidade permanente para } \\
\text { coberturas com prata. }\end{array}$ \\
\hline
\end{tabular}


Table 1 - Mean percentage of correct scores of research participants by sociodemographic/educational variables, Ribeirão Preto, São Paulo, Brazil, 2016

\begin{tabular}{|c|c|c|c|c|}
\hline & $\begin{array}{l}\text { Prevention } \\
\text { (29 items) }\end{array}$ & $\begin{array}{l}\text { Staging } \\
(20 \text { items })\end{array}$ & $\begin{array}{l}\text { Wound } \\
\text { (23 items) }\end{array}$ & $\begin{array}{c}\text { Total } \\
\text { (72 items) }\end{array}$ \\
\hline \multicolumn{5}{|c|}{ Time of practice (years) } \\
\hline Less than 1 & $67.2 \%$ & $47.5 \%$ & $65.2 \%$ & $61.1 \%$ \\
\hline 1 to 5 & $72.7 \%$ & $70.7 \%$ & $65.0 \%$ & $69.7 \%$ \\
\hline 5 to 10 & $72.8 \%$ & $67.5 \%$ & $70.7 \%$ & $70.7 \%$ \\
\hline 10 to 15 & $70.4 \%$ & $69.3 \%$ & $67.7 \%$ & $69.2 \%$ \\
\hline 15 to 20 & $68.5 \%$ & $65.0 \%$ & $65.2 \%$ & $66.5 \%$ \\
\hline 20 or more & $73.7 \%$ & $69.4 \%$ & $66.3 \%$ & $70.1 \%$ \\
\hline \multicolumn{5}{|c|}{ Highest degree obtained } \\
\hline Baccalaureate & $71.0 \%$ & $68.8 \%$ & $65.5 \%$ & $68.6 \%$ \\
\hline Master & $77.0 \%$ & $63.3 \%$ & $69.6 \%$ & $70.8 \%$ \\
\hline $\mathrm{PhD}$ & $82.8 \%$ & $100.0 \%$ & $65.2 \%$ & $81.9 \%$ \\
\hline Other & $70.6 \%$ & $66.2 \%$ & $67.6 \%$ & $68.4 \%$ \\
\hline \multicolumn{5}{|c|}{$\begin{array}{l}\text { Searched for information on } \\
\text { pressure injury on the Internet? }\end{array}$} \\
\hline Yes & $72.4 \%$ & $69.0 \%$ & $67.0 \%$ & $69.7 \%$ \\
\hline No & $63.8 \%$ & $57.5 \%$ & $59.8 \%$ & $60.8 \% *$ \\
\hline \multicolumn{5}{|c|}{$\begin{array}{l}\text { Read the international } \\
\text { guidelines set forth by the } \\
\text { National Pressure Ulcer } \\
\text { Advisory Panel/European } \\
\text { Pressure Ulcer Advisory Panel? }\end{array}$} \\
\hline Yes & $77.3 \%$ & $71.3 \%$ & $67.8 \%$ & $72.6 \%$ \\
\hline No & $70.2 \%$ & $67.3 \%$ & $66.0 \%$ & $68.1 \%$ \\
\hline Total & $71.8 \%$ & $68.1 \%$ & $66.4 \%$ & $69.1 \%$ \\
\hline
\end{tabular}

Note: ${ }^{*}=p<0,05$

Significant differences were also found between the total test scores of individuals who had searched for information on the internet about pressure injury/ulcers and those who had not.

The results show that all the participants obtained over $50 \%$ of correct scores, being that $44.4 \%$ scored between $70 \%$ and $80 \%$. On comparing the percentage of correct scores between types of highest degrees obtained, all the professionals with master's or PhD degrees obtained scores higher than $60 \%$, whereas most $(57.2 \%)$ of the participants with specialization degrees presented scores higher than $70 \%$.

Attending lectures was shown to influence test performance, with $71.4 \%$ of the individuals who had attended a lecture in the year prior to the study scoring between $50 \%$ and $90 \%$.

Most $(52 \%)$ of the participants who reported using the internet to search for information on the theme scored higher percentages of correct answer, between $70 \%$ and $90 \%$. Of the 12 participants who had read the NPUAP/EPUAP guideline, 9 $(75.0 \%)$ scored between $70 \%$ and $90 \%$. Of the 42 who had not read the guideline, 25 (59.5\%) scored lower than $70 \%$.

The participants in the pre-testing phase expressed no difficulty in understanding the questionnaire and no suggestions were made.

Cronbach's alpha for the 72 items was 0.825 , but for the sub-scales, it was: 0.379 for prevention; 0.421 for staging, and 0.349 for wound description. The overall value was higher than 0.70 , which indicates that the Portuguese version of the PZ-PUKET was valid for the sample.

\section{DISCUSSION}

The methodological process adopted in the cultural adaptation of the Portuguese version of the Pieper-Zulkowski Pressure Ulcer Knowledge Test (PZ-PUKT), described in the present study, was in accordance with the scientific literature ${ }^{(26-27)}$. The Portuguese version was named "Pieper-Zulkowski Teste de Conhecimento sobre Lesão por Pressão (PZ-TCLP)" (the Pieper-Zulkowski knowledge test about pressure injury - PZ-TCLP).

After the translation, the assessment by the expert panel was an important step to identify terms that might not be understood by the target audience and thus change them before the back translation process. The assessment of the back translation was enhanced by the contributions of the authors of the original version, who reviewed and changed terms and items, with the goal of increasing their clarity and comprehension. This step included establishing contact via email with the authors to clarify aspects related to terms and concepts, which led to changes in 7 items. Thus, the name of the original version in English was changed to PZ-PUKT - Version 2.

In April 2016, the NPUAP(3) announced the change in terminology from pressure ulcer (PU) to pressure injury (PI). Thus, the term PU adopted in the PZ-PUKT had to be reviewed. After pertinent considerations, and considering that in Brazil, the term "pressure ulcer" is widely used, the authors agreed that the items in the Portuguese version would adopt the new term (PI), together with the original term (PU), or "pressure ulcer/injury".

After the final Portuguese version was obtained, the main author looked up the 72 items in the NPUAP guidelines to verify to which sub-scale they belonged: prevention, staging or wound description. The new PZ-PUKT items and the items that came from the original PUKT test were reallocated, when necessary, based on expert agreement and in accordance with the consulted literature ${ }^{(2,15-16)}$.

The questionnaire demonstrated content validity as per the opinion of the expert panel, which means that its adaptation was suitable to the Brazilian context. Reliability presented an adequate Cronbach's alpha for internal consistency of the test items in the studied sample, values similar to other studies developed in Brazil ${ }^{(30-33)}$.

The pre-testing phase is essential to the translation and cross-cultural adaptation of questionnaires ${ }^{(26-27)}$. Considering the sociodemographic and educational characteristics of the participants, most were young, female, with a graduate degree in nursing as their highest degree, and only $2(3.7 \%)$ with a specialization degree in stomatherapy. In Brazil, studies have indicated a predominance of women in hospital nursing services ${ }^{(30,34-35)}$, as well as a shortage of injury nursing specialists, considering that few institutions have specialized nurses on staff(22).

Compared with the results obtained in the United States ${ }^{(24)}$, the authors of the original version found that most of the participants were also female and most had baccalaureate degrees. Furthermore, $21(22 \%)$ had specialized in wound care. 
Level of education influenced the percentage of correct answers, considering that professionals with Master's and PhD degrees and/ or clinical specialization presented higher scores than other participants in the study. Prior studies about the knowledge of nurses in Brazilian university hospitals and nursing professors about PI classification, prevention and treatment have shown that professionals with specialization degrees obtained the highest scores ${ }^{(14,16,19,35)}$.

Ongoing professional development also contributed to higher scores, with significant differences among participants who had attended lectures and searched for information on the internet. Those who had read the NPUAP/EPUAP clinical practice guideline on the prevention and treatment of pressure ulcers obtained scores above $70 \%$. These results corroborate those found by the authors of the original questionnaire ${ }^{(24)}$. Nurses must base their practice on updated scientific knowledge to promote the best care possible to chronic wound patients ${ }^{(22-23)}$.

The results of this study in terms of the total test score (72 items) and the sub-scale scores were lower than those found in the original American study ${ }^{(24)}$.

In both the present study and the original study, the results for the internal consistency of the total test items were satisfactory. However, in both, Cronbach's alpha for the sub-scales was lower than $0.70^{(24)}$.

The present study showed that the adapted version of the PZ-PUKT presented face and content validity, and also carried out an initial analysis of its internal consistency. Future studies using representative samples will be carried out to assess other aspects relative to the psychometric properties of the PZ-TCLP.

\section{Limitations of the study}

The main focus of the present study was the translation and adaptation of the questionnaire for use in Brazil and the analysis of the psychometric properties was preliminary.

\section{Contributions to nursing}

At the end of the validation process, the questionnaire can be used in intervention studies to measure the variable "nursing knowledge about pressure injury/ulcers."

\section{CONCLUSION}

The present study addressed the translation and cross-cultural adaptation process of the PZ-PUKT for use in Brazil. The PZTCLP demonstrated content validity according to the opinion of the expert panel, meaning that it is an adequate adaptation for the Brazilian context. Analysis of internal consistency showed satisfactory results considering the total test. However, further studies are needed to consolidate the validity of the PZ-TCLP before making it available to be administered reliably.

\section{REFERENCES}

1. Mendes EV. O cuidado das condições crônicas na atenção primária à saúde: o imperativo da consolidação da estratégia da saúde da família. Brasília: Organização Pan-Americana da Saúde; 2012. 512 p.

2. National Pressure Ulcer Advisory Panel-NPUAP. European Pressure Ulcer Advisory Panel-EPUAP. Pan Pacific Pressure Injury Aliance-PPPIA. Prevention and treatment of pressure ulcers: clinical practice guideline. Osborne Park: Cambridge Media; 2014.

3. National Pressure Ulcer Advisory Panel Responds to Editorial. Adv Skin Wound Care [Internet]. 2016[cited 2017 Jan 03];29(12):535. Available from: https://www.ncbi.nlm.nih.gov/pubmed/27846025

4. Wounds International Guidelines. Pressure ulcer prevention: prevalence and incidence in context: a consensus document. London: MEP; 2009.

5. Moura GMSS, Magalhães AMM. Eventos adversos relacionados à assistência em serviços de saúde: principais tipos. Assistência segura: uma reflexão teórica aplicada à prática. Brasília: Agência Nacional de Vigilância Sanitária; 2013.

6. Pieper B, (Ed.). National Pressure Ulcer Advisory Panel-NPUAP. Pressure ulcers: prevalence, incidence, and implications for the future. Washington: NPUAP; 2012.

7. Bernardes RM, Caliri MHL. Pressure ulcer prevalence in emergency hospitals: a cross-sectional study. O Braz J Nurs[Internet] 2016 [cited 2017 Jan 03];15(2):236-44. Available from: http://www.objnursing.uff.br/index.php/nursing/article/view/5391

8. Gonçalves MBB, Rabeh SAN, Nogueira PC. Terapia tópica em ferida crônica: recomendações para a prática baseada em evidências. Rev Estima [Internet]. 2014 [cited 2017 Jan 12];12(1):42-9. Available from: https://www.revistaestima.com.br/index.php/estima/ article/view/337

9. Rangel EML, Caliri MHL. Uso das diretrizes para tratamento da úlcera por pressão por enfermeiros de um hospital geral. Rev Eletron Enf [Internet] 2009 [cited 2017 Jan 12];11(1):70-7. Available from: https://www.fen.ufg.br/fen revista/v11/n1/pdf/v11n1a09.pdf

10. Pieper B, Mott M. Nurses' knowledge of pressure ulcer prevention, staging, and description. Adv Wound Care [Internet]. 1995[cited 2017 Jan 12];8(3):34-8. Available from: https://www.ncbi.nlm.nih.gov/pubmed/7795877

11. Pieper B, Mattern JC. Critical care nurses' knowledge of pressure ulcer prevention, stating and description. Ostomy Wound Manag[Internet]. 1997[cited 2017 Jan 12];43(2):22-1. Available from: https://www.ncbi.nlm.nih.gov/pubmed/9136995

12. Sinclair L, Berwiczonek H, Thurston N, Butler S, Bulloch G, Ellery C, et al. Evaluation of an evidence-based education program for pressure ulcer prevention. J Wound Ostomy Cont Nurs [Internet]. 2004 [cited 2017 Jan 12];31(1):43-50. Available from: https:// www.ncbi.nlm.nih.gov/pubmed/15128094

13. Caliri MHL, Miyazaki MY, Pieper B. Knowledge of pressure ulcers by undergraduate nursing students in Brazil. Ostomy Wound Manag [Internet]. 2003[cited 2017 Jan 12];49(3):54-63. Available from: https://www.ncbi.nlm.nih.gov/pubmed/12732751 
14. Rangel EML. Conhecimento, práticas e fontes de informação de enfermeiros de um hospital sobre a prevenção e tratamento da úlcera por pressão. [Dissertação]. Escola de Enfermagem de Ribeirão Preto, Universidade de São Paulo, Ribeirão Preto; 2004.

15. Fernandes L, Caliri MHL, Haas VJ. The effect of educative interventions on the pressure ulcer prevention knowledge of nursing professionals. Acta Paul Enferm [Internet]. 2008 [cited 2017 Jan 15];21(2):305-11. Available from: http://www.scielo.br/pdf/ape/ v21n2/a12v21n2.pdf

16. Miyazaki MY, Caliri MHL, Santos CB. Conocimiento de los profesionales de enfermería sobre prevención de la úlcera por presión. Rev Latino-Am Enfermagem[Internet]. 2010[cited 2017 Jan 15];18(6):1203-11. Available from: http://www.scielo.br/pdf/rlae/v18n6/22.pdf

17. Poletti NAA. O ensino da prevenção e tratamento de úlceras por pressão em escolas públicas do estado de São Paulo. [Tese] Escola de Enfermagem de Ribeiro Preto, Universidade de São Paulo. Ribeirão Preto; 2005. $152 f$.

18. Rabeh SAN, Gonçalves MBB, Caliri MHL, Nogueira PC, Miyazaki MY. Construção e validação de um módulo educativo virtual para terapia tópica em feridas crônicas. Rev Enferm UERJ [Internet]. 2012 [cited 2016 Dec 21];20(Esp.1):603-8. Available from: http://www.e-publicacoes.uerj.br/index.php/enfermagemuerj/article/view/5819/4229

19. Gonçalves MBB, Rabeh SAN, Terçariol CAS. The contribution of distance learning to the knowledge of nursing lecturers regarding assessment of chronic wounds. Rev Latino-Am Enfermagem [Internet]. 2015[cited 2016 Dec 21];23(1):122-9. Available from: http:// www.scielo.br/pdf/rlae/v23n1/0104-1169-rlae-23-01-00122.pdf

20. Souza TS, Maciel OB, Méler MJ, Danski MTR, Lacerda MR. [Clinical studies on pressure ulcer]. Rev Bras Enferm[Internet]. 2010[cited 2017 Jan 18];63(3):470-6. Available from: http://www.scielo.br/pdf/reben/v63n3/a20v63n3.pdf Portuguese

21. Conselho Federal de Enfermagem - Cofen. Resolução Cofen 358/2009. Dispõe sobre a Sistematização da Assistência de Enfermagem e a implementação do Processo de Enfermagem em ambientes, públicos ou privados, em que ocorre o cuidado profissional de Enfermagem, e dá outras providências. Available from: http://www.cofen.gov.br/resoluo-cofen-3582009_4384.html

22. Caliri MHL, Chayamiti EMPC, Rabeh SAN, Miyazaki MY. Novas tecnologias no cuidado de feridas. In: Associação Brasileira de Enfermagem. Teixeira E, Bresciani HR, Martini JG, (Orgs.). Programa de Atualização em Enfermagem-PROENF: Saúde do Adulto: Ciclo 8. Porto Alegre: Artmed Panamericana; 2013. p. 149-82. (Sistema de Educação em Saúde Continuada a Distância; v.3).

23. Santos CT, Almeida MA, Lucena AF. The Nursing Diagnosis of risk for pressure ulcer: content validation. Rev Latino-Am Enfermagem [Internet]. 2016 [cited 2017 Jan 12];24:e2693. Available from: http://www.scielo.br/pdf/rlae/v24/0104-1169-rlae-24-02693.pdf

24. Pieper B, Zulkowski K. The Pieper-Zulkowski pressure ulcer knowledge test. Adv Skin Wound Care [Internet]. 2014 [cited 2017 Jan 07];27(9):413-20. Available from: http://dx.doi.org/10.1097/01.ASW.0000453210.21330.00

25. National Pressure Ulcer Advisory Panel-NPUAP. European Pressure Ulcer Advisory Panel-EPUAP. Prevention and treatment of pressure ulcers: clinical practice guideline. Washington: National Pressure Ulcer Advisory Panel; 2009.

26. Beaton DE, Bombardier C, Guillemin F, Ferraz MB. Guidelines for process of cross-cultural adaptation of self-report measures. Spine [Internet]. 2000 [cited 2016 Dec 02]; 25(24): 3186-91. Available from: https://www.researchgate.net/publication/12203631 Guidelines for_the_Process_of_Cross-Cultural_Adaption_of_Self-Report_Measures. http://dx.doi.org/10.1097/00007632-200012150-00014

27. Ferrer M, Alonso J, Prieto L, Plaza V, Monsó E, Marrades R, et al. Validity and reliability of the St George's Respiratory Questionnaire after adaptation to a different language and culture: the Spanish example. Eur Respir J [Internet]. 1996 [cited 2016 Dec 02];9:11606. Available from: http://dx.doi.org/10.1183/09031936.96.09061160

28. Portney LG, Watkins MP. Foundations of clinical research - applications to practice.3th. ed. New Jersey: Prentice Hall; 2009.892 p.

29. Tavakol M, Dennick R. Making sense of Cronbach's alpha. Int J Med Educ [Internet]. 2011 [cited 2016 Dec 02];(2):53-5. Available from: https://www.ijme.net/archive/2/cronbachs-alpha.pdf

30. Siqueira LDC, Caliri MHL, Kalisch B, Dantas RAS. Cultural adaptation and internal consistency analysis of the MISSCARE Survey for use in Brazil. Rev Latino-Am Enfermagem [Internet]. 2013[cited 2016 Nov 30];21(2):610-17. Available from: http://www.scielo. $\mathrm{br} / \mathrm{pdf} / \mathrm{rlae} / \mathrm{v} 21 \mathrm{n} 2 / 0104-1169-\mathrm{rlae}-21-02-0610 . p d f$

31. Domingues EAR, Alexandre NMC, Silva JV. Cultural adaptation and validation of the Freiburg Life Quality Assessment - Wound Module to Brazilian Portuguese. Rev Latino-Am Enfermagem [Internet]. 2016[cited 2016 Nov 24];24:e2684. Available from: http:// www.scielo.br/pdf/rlae/v21n2/0104-1169-rlae-21-02-0610.pdf

32. Figueiredo AEPL, Rocha K, Araya SB, Catoni MI, Schilling MCL, Urbanetto JS. Translation and adaptation to Portuguese of the haemodialysis patient assessment tool - CUDYR-DIAL. Rev Gaúcha Enferm [Internet]. 2016[cited 2017 Jan 07];37(1):e56244. Available from: http://www.scielo.br/pdf/rgenf/v37n1/en_0102-6933-rgenf-1983-144720160156244.pdf

33. Freitas NO, Caltran MP, Dantas RAS, Rossi LA. Translation and cultural adaptation of the Perceived Stigmatization Questionnaire for burn victims in Brazil. Rev Esc Enferm USP [Internet]. 2014 [cited 2016 Dec 05];48(1):25-33. Available from: http://www.scielo. $\mathrm{br} / \mathrm{pdf} /$ reeusp/v48n1/0080-6234-reeusp-48-01-25.pdf

34. Marques LG, Vieira MLC, Pereira SEM. A construção do conhecimento dos enfermeiros perante a nova classificação da úlcera por pressão. Rev Estima [Internet]. 2013 [cited 2017 Jan 18];11(1). Available from: https://www.revistaestima.com.br/index.php/ estima/article/view/80

35. Santos MV, Cerqueira PV, Moura ECC, Silva GRF, Falcão LM. Satisfação de enfermeiros com curso de formação para operacionalização de protocolo sobre úlcera por pressão. Rev Rene [Internet]. 2015 [cited 2017 Jan 13];16(4):496-503. Available from: http://www. redalyc.org/articulo.oa? $\mathrm{id}=324041519006$ 